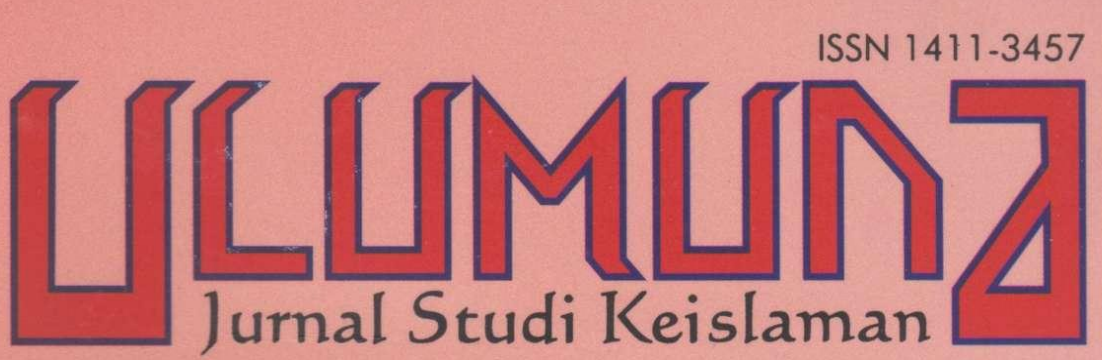
Volume XIV• Nomor 1• Juni 2010

TERAKREDITASI Berdasarkan SK Dirjen Dikti Depdiknas Nomor: 65a/DIKTL/Kep/2008

FILSAFAT ISLAM: ANTARA DUPLIKASI DAN KREASI Abdullah Satar

AL-HIKMAH AL-MUTA'ÂLIYAH: PEMIKIRAN METAFISIKA EKSISTENSIALISTIK MULLA SHADRA Sholihan

HERMENEUTIKA AL-QUR'AN: ANTARA PEMAKNAAN TEKSTUAL DAN KONTEKSTUAL Slamet Mulyono R

MENIMBANG KEMBALI PARADIGMA FILSAFAT ISLAM DALAM BANGUNAN KEILMUAN ISLAM KONTEMPORER Aksin Wijaya

KONTRIBUSI FILSAFAT ILMU DALAM STUDI ILMU AGAMA ISLAM: TELAAH PENDEKATAN FENOMENOLOGI Mulyadi

SIGNIFIKANSI TEORI POPPER, KUHN, DAN LAKATOS TERHADAP PENGEMBANGAN ILMU-ILMU KEISLAMAN Ahmad Choirul Rofiq 
TransLiterasi

Artikel

Abdullah Sattar

Sholihan

Suhermanto Ja'far

Abdul Mukti Ro'uf

Aksin Wijaya

Mulyadi

Slamet Muliono R. Hermeneutika Al-Qur'an:

Antara Pemaknaan Tekstual

dan Kontekstual • 101-120

Menimbang Kembali Paradigma Filsafat

Islam dalam Bangunan Keilmuan Islam

Kontemporer $\bullet 121-144$

Konstribusi Filsafat Ilmu dalam

Studi Ilmu Agama Islam: Telaah

Pendekatan Fenomenologi • 145-176

Ahmad Choirul Rofiq Signifikansi Teori Popper, Kuhn, dan

Lakatos terhadap Pengembangan

Ilmu-Ilmu Keislaman • 177-196

Win Usuluddin

Elusidasi Filosofis Kebhinekaan

Keagamaan: Refleksi atas Pluralisme

Keberagamaan Era Postmodern • 197-226

\section{INDEKS}




\section{PEDOMAN TRANSLITERASI}

\begin{tabular}{|c|c|c|c|c|c|}
\hline Arab & & Latin & Arab & & Latin \\
\hline 1 & $=$ & $\mathrm{a}$ & ف & $=$ & $\mathrm{f}$ \\
\hline ب & $=$ & $\mathrm{b}$ & ق & $=$ & $\mathrm{q}$ \\
\hline$ت$ & $=$ & $\mathrm{t}$ & ك5 & $=$ & $\mathrm{k}$ \\
\hline$\dot{H}$ & $=$ & ts & ل - ل ل & $=$ & 1 \\
\hline 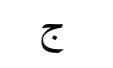 & $=$ & $\mathrm{j}$ & s & $=$ & $\mathrm{m}$ \\
\hline$\tau$ & $=$ & $\underline{\mathrm{h}}$ & ن ن & $=$ & $\mathrm{n}$ \\
\hline$\dot{\tau}$ & $=$ & $\mathrm{kh}$ & و & $=$ & $\mathrm{w}$ \\
\hline د & $=$ & $\mathrm{d}$ & 。 & $=$ & $\mathrm{h}$ \\
\hline$\dot{~}$ & $=$ & $\mathrm{dz}$ & $\Leftrightarrow$ & $=$ & , \\
\hline J & $=$ & $\mathrm{r}$ & ي & $=$ & $\mathrm{y}$ \\
\hline j & $=$ & $\mathrm{z}$ & & & \\
\hline س س & $=$ & $\mathrm{s}$ & & & \\
\hline ش & $=$ & sy & \multirow{2}{*}{\multicolumn{3}{|c|}{$\begin{array}{l}\text { Untuk Madd } \\
\text { dan Diftong }\end{array}$}} \\
\hline ص ص & $=$ & sh & & & \\
\hline ض ض & $=$ & $\mathrm{dl}$ & $i$ & $=$ & â (a panjang) \\
\hline b & $=$ & th & إي & $=$ & $\hat{i}$ (i panjang) \\
\hline ظ & $=$ & $\mathrm{zh}$ & 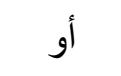 & $=$ & û (u panjang) \\
\hline$\varepsilon$ & $=$ & 6 & او - او & $=$ & aw \\
\hline$\dot{\varepsilon}$ & $=$ & gh & أي & $=$ & ay \\
\hline
\end{tabular}




\title{
ELUSIDASI FILOSOFIS KEBHINEKAAN \\ KEAGAMAAN: REFLEKSI ATAS PLURALISME \\ KEBERAGAMAAN ERA POSTMODERN
}

Win Usuluddin*

\begin{abstract}
As noted in its wide history, religious pluralism has been understood and accepted variously. Elucidation on the religious pluralism in the postmodern era seems to be a necessity since religious pluralism has more than one interpretation. Religious pluralism is often seen as the same as plurality or even inclusivity, and religious relativism. This paper tries to explore the suspension of that pluralism and let the readers to examine it. Sequentially, this paper is begun with the short introduction related to religious pluralism in the West and in Islam. Furthermore, the paper tries to elaborate the relationship between religious pluralism and religious philosophy; explores religious philosophical perspective on pluralism, the certainty of plurality, the function of philosophy in religious distinction, some crucial aspects in religion, and religiosity in the postmodern era. As a closing, the writer tries to urge readers to reflect the religiosity in the postmodern era.
\end{abstract}

Abstrak: Sebagaimana tercatat dalam sejarah panjangnya, pluralism agama dipabami dan diterima dengan cara yang beragam. Elusidasi atas pluralisme agama pada era posmodernisme tampaknya menjadi sesuatu yang niscaya, karena pluralism agama memiliki lebih dari satu macam interpretasi. Pluralism agama kerap kali dipandang sama artinya dengan pluralitas, inklusifitas, dan relitifisme agama. Tulisan ini berupaya mengeksplorasi ketegangan dari pluralism itu and menyerabkan penilaiannya kepada para pembaca. Secara berurutan, tulisan ini diawali dengan pengantar ringkas yang terkait dengan pluralism agama di Barat dan Islam. Lebih jaub lagi, tulisan ini berupaya untuk mengelaborasi bubungan antara pluralism agama dan filsafat agama; mengneksplorasi perspektif filsafat agama tentang pluralisme, kepastian pluralitas, fungsi filsafat dalam perbedaan agama, beberapa aspek krusial dalam agama, dan keberagamaan di era posmoderen. Sebagai pemungkasnya, penulis mencoba mendorong pembaca untuke merefleksikean religiusitas di era posmoderen.

Keywords: Elusidasi Filosofis, Pluralisme Agama, Filsafat Agama, Era Postmodern.

*Penulis adalah dosen pada Sekolah Tinggi Agama Islam Negeri (STAIN) Jember. email: win_bernadien@yahoo.co.id. 
DALAM bentangan historisitas keberagamaan umat Islam di Indonesia, sesungguhnya pikiran tentang bhineka tunggal eka itu tidak saja ada dalam kontes legal-formal berbangsa dan bernegara tetapi juga telah ada dalam praktek-praktek keberagamaan. Lihat saja misalnya di sebagian kalangan masyarakat Jawa, agama itu telah lama dijawakan menjadi "ageman" artinya "pakaian" yang sudah barang tentu corak, kelir, mode, dan ukurannya pun sangat beragam sesuai dengan selera pemakainya. Dalam perspektif ini, pakaian kemudian menjadi simbol bagi alter-ego (keakuan yang lain), fungsinya sebagai pengganti bagi seseorang sehingga seolah seseorang itu mendapat kepribadian baru, dan selanjutnya tentu secara interpretatif pakaian dapat dimaknai sebagai tabir yang dapat menutupi tubuh (dan sekaligus bagian yang paling pribadi) pemakainya dari pandangan khalayak. Tulisan ini memang tidak hendak memperbincangkan pluralisme keagamaan di Indonesia tetapi hendak mengatakan bahwa senyatanya pikiran tentang pluralisme agama itu telah ada sejak lama, meskipun memang harus diakui bahwa akhir-akhir ini pikiran itu telah menjelma menjadi sebuah paham dan gerakan "baru" yang kehadirannya serasa begitu mendadak, tiba-tiba, dan mengejutkan.

Pluralisme sebagai paham yang muncul di Barat pada era Modern itu semakin berkembang pesat pada (era) postmodern yang kemudian banyak merasuk ke dalam pemikiran masyarakat luas tak terkecuali sebagian masyarakat muslim. Kalangan umat Islam pendukung paham ini mencari-cari akarnya dari kondisi masyarakat Islam di masa lalu, dan kemudian beranggapan bahwa pluralitas agama dan paham pluralisme agama itu sama saja. Mereka yakin, pluralitas dan pluralisme agama dalam Islam telah ada sejak Piagam Madinah dicanangkan, bahkan diyakini bahwa pluralitas dan pluralisme agama adalah sunnatullah. Namun bagi sebagian masyarakat muslim yang menolak atas pandangan tersebut memberikan penjelasan bahwa pluralitas agama itu tidak sama dengan pluralisme agama. Pluralitas agama adalah kondisi di mana berbagai macam agama secara bersamaan hadir dalam masyarakat, sedangkan pluralisme agama adalah suatu paham yang menjadi tema penting dalam disiplin sosiologi, teologi, dan filsafat agama yang berkembang di Barat dan 
belakangan kemudian diketahui sebagai agenda penting globalisasi. Selanjutnya, kelompok ini beranggapan bahwa dalam Islam, pluralitas agama adalah pengakuan atas perbedaan dan identitas agama masing-masing, ${ }^{1}$ bukan malah menghilangkan perbedaan dan identitas agama-agama yang ada. Dengan kata lain, menganggap pluralisme agama sebagai sunnatullah adalah klaim yang mungkin berlebihan bahkan mungkin tidak benar.

Perlu diungkapkan di sini bahwa dalam paham pluralisme agama yang berkembang di Barat terdapat sekurang-kurangnya dua aliran yang berbeda, yaitu: paham teologi global (global theology), dan paham kesatuan transenden agama-agama (Transcendent Unity of Religions). Menurut Hamid Fahmy Zarkasyi baik global theology maupun Transcendent Unity of Religions telah sama-sama membangun gagasan, konsep, dan prinsipnya masing-masing, untuk kemudian akhirnya menjadi paham yang sistemik. Lebih jauh Hamid menjelaskan bahwa dua aliran di atas muncul disebabkan oleh dua motif yang berbeda, meskipun keduanya sama-sama muncul di Barat, tetapi yang satu justru menyalahkan yang lain. Aliran teologi global fokus pada kajian sosiologis, motif terpentingnya adalah tuntutan modernisasi dan globalisasi. Aliran ini berkeyakinan bahwa agama di era globalisasi adalah institusi yang sangat penting sehingga hubungan globalisasi dan agama menjadi tema sentral dalam sosiologi agama. Dianggap penting karena proyek globalisasi dan kapitalisme digunakan untuk mengurangi atau bahkan menghapus otoritas agama, politik, militer dan sumber kekuasaan lainnya.

Cara yang ditempuh dalam program globalisasi ini adalah dengan mendorong semua pihak agar menjadi terbuka dan bebas menerima berbagai ideologi dan nilai-nilai sosial yang "dianggap" universal. Pergumulan pemikiran untuk menjadikan agama akomodatif terhadap tuntutan sosial agaknya lebih dominan ketimbang upaya menciptakan masyarakat religius. Dalam sejarahnya Barat memang berhadapan dengan doktrin agama Kristen yang eksklusif, dengan doktrin "di luar gereja tidak ada keselamatan", meskipun pada akhirnya doktrin itu bergeser

${ }^{1}$ Qs. al-Kâfirûn (110): 6. 
menjadi penerimaan semua yang menyembah Tuhan sebagai termasuk ke dalam agama Kristen (inklusif). Doktrin inkusif inilah yang akhirnya bergeser menjadi pluralisme. ${ }^{2}$ Sementara itu aliran Transenden Unity of Religions didominasi oleh pendekatan filosofis dan teologis Barat, yakni memakai pendekatan religious filosofis. Bagi kelompok ini agama tidak bisa diubah begitu saja dengan mengikuti zaman globalisasi, zaman modern atau pun postmodern. Agama tidak bisa dilihat hanya dari perspektif sosiologis atau historis saja apalagi dihilangkan identitasnya.

Konsep utama kelompok ini adalah sophia perrenis yang dalam agama Hindu dikenal dengan Sanata Dharma atau dalam bahasa Arab dikenal dengan istilah al-Hikmah al-Khâlidah, sebuah pandangan bahwa di dalam setiap agama selalu saja terdapat tradisi sakral yang perlu dihidupkan dan dipelihara secara adil, tanpa menganggap yang satu lebih superior dari pada yang lain. Agama bagi aliran ini adalah jalan menuju ke puncak yang sama. Inilah yang dimaksud dengan Transcendent Unity of Religions Fritjhof Schuon. Pendekatan yang diambil aliran ini berasal dari pengalaman spiritual dari tradisi mistik berbagai agama. Dalam kasus Islam mereka mengambil pengalaman spiritual kaum sufi, yang mereka anggap pluralis.

\section{Jalinan Pluralisme Agama dan Filsafat Agama}

Pluralisme agama, Zarkasyi, ${ }^{3}$ sesunguhnya merupakan upaya agar doktrin agama tunduk pada kondisi sosial dan tuntutan akal manusia. Dengan kata lain diskursus agama "harus" berada di tangan para filosof, terutama filosof aktifis atau mantan aktifis

2Paham ini diusung oleh John Hick dengan teori teologi globalnya (global theology). Sejalan dengan itu Wilfred Cantwell Smith, pendiri McGill Islamic Studies mengajukan teori teologi dunia (world theology). Baik Hick maupun Smith sama-sama membawa paham tentang "satu teologi untuk semua agama di selurub dunia". Mereka yakin bahwa semua agama akan berevolusi dan akan saling mendekat yang pada akhirnya akan melebur menjadi satu teologi yang disebut teologi global (global theology). Selebihnya lihat: http://www.hidayatullah. com/kolom/ worldviews/10502-pluralisme.html, diakses tanggal 20 Februari 2010.

3 Selebihnya baca: Hamid Fahmy Zarkasyi dalam http://www.hidayatullah. com/kolom/ worldviews/10502-pluralisme.html, diakses tanggal 20 Maret 2010. 
gerakan Protestan Liberal yang mencari "rumah baru" untuk memberi tempat bagi diskusi mereka tentang agama. "Rumah Baru" itu adalah philosophy of religion yang berakar pada comparative religion, bukan teologi. Di "rumah baru" ini pembahasan agama bebas dari paham suatu agama tertentu, yang ada hanyalah pluralisme agama. Wacana pluralisme agama yang kini telah menjadi "doktrin" ini kemudian masuk dalam diskusi tentang toleransi beragama, kerukunan beragama, inter-faith dialogue, dan semacamnya. Searah dengan hal tersebut perlu diungkap bahwa Filsafat Agama adalah suatu disiplin ilmu yang metode dan teorinya berasal dari filsafat, objeknya adalah semua agama. Sudah barang tentu filsafat tatkala membahas agama-agama itu, 'worldview' filsafat berada pada posisi 'bird-eyes', doktrin filsafat berada di atas doktrin agama. Dalam era globalisasi disiplin ilmu ini kemudian dikembangkan menjadi Filsafat Agama Lintaskultural (cross-cultural philosophy of religion). Hal ini berarti bahwa objek kajian filsafat agama diperluas dari sekedar agama yang ada dalam suatu kultur menjadi agama dan kepercayaan yang berasal dari kultur lain, dan sudah barang tentu metode dan cara pandangnya pun tetap pemikiran filsafat, sosiologi, dan antropologi. Dalam kontes yang seperti ini, agama hanya dianggap sebagai produk kreatifitas manusia dan akan terus berubah sebagaimana living organism yang lain.

Dalam lintasan sejarahnya, sesungguhnya benih-benih disiplin ilmu filsafat agama itu disemai oleh Ninian Smart, seorang filosof dan sejarawan Cambridge yang pada tahun 1958 menerbitkan karya filsafat agama berjudul Reason and Faith. Baginya filsafat dan sejarah agama harus bekerjasama, agar filsafat agama dapat berperan penting dalam kebudayaan yang pluralistis dan global pada akhir Abad XX. Selama hampir dua puluh tahun buku ini belum tertandingi dan dianggap pioneer dalam bidangnya. ${ }^{4}$ Periode pengembangan terjadi pada tahun 1960-an ditandai oleh peluncuran karya Wilfred Cantwell Smith berjudul The Meaning and End of Religion. Karya ini dianggap telah membuka jalan bagi formulasi baru bagi problematika pemahaman agama lintas kultural, dan menjadi penting karena

${ }^{4}$ http://en.wikipedia.org/wiki/Ninian Smart., diakses tanggal 23 Maret 2010. 
selain mendukung pandangan bahwa kehidupan keagamaan manusia adalah sebuah dynamic historical continuum, juga menolak klaim kelompok transendentalis seperti Rene Guenon, Schuon, Hossen Nasr yang menganggap agama-agama di dunia secara konseptual merupakan sistem tertutup. Wacana ini kemudian mendapat sokongan dari para filosof dan ilmuwan bidang agama. Buktinya pada tahun 1972, terbit essay analitis yang ditulis oleh William Christian berjudul Opposition of Religious Doctrines. Ditambah lagi ketika terbit karya bungarampai para filosof dan pakar sejarah agama yang disunting oleh John Hick pada tahun 1974 berjudul Truth and Dialogue in World Religions: Conflicting Truth-Claim. Disusul kemudian oleh Raimundo Panikkar dengan bukunya, The Intrareligious Dialogue (1978), dan Hick sendiri menulis buku Philosophy of Religion. Sebagai titik kulminasi dari wacana ini adalah karya Wilfred Smith yang berjudul Towards World Teology, dan karya John Hick berjudul Problems of Religious Pluralism (1985) dan pada tahun 1987 Interpretation of Religion karya Gifford Lecture. Di dalam karyanya inilah Hick mendeklarasikan perlunya teologi global, itulah pluralisme agama. Goal getternya adalah Smith dan Hick. Jelas sudah bahwa hubungan antara doktrin pluralisme agama dengan pemikiran filosof dan saintis sangat erat. Smith yang mangadopsi teori Newtonian Revolution menganggap berbagai agama sebagai hamparan planet yang memiliki hukum gravitasi dan pergerakan yang sama, hukum agama pun tidak hanya berlaku pada satu agama saja, tapi untuk semua agama. Jika Copernicus memindahkan pusat gravitasi dari bumi ke matahari maka Hick memindahkan pusat gravitasi teologi dari agama-agama kepada Tuhan (Religioncentredness to God centredness), dalam bahasa lain Hick memindahkan keberagamaan dari individu kepada Realitas Mutlak (self-centredness to Reality centredness).

\section{Pluralisme Bukan Inklusivisme: Perspektif Filsafat Ketuhanan}

Pluralisme keagamaan, jelas merupakan tantangan yang bersifat khas di era postmodern saat ini. Mengapa? karena pada era postmodern keterbukaan adalah sebuah keniscayaan. Lebih dari itu kemungkinan komunikasi yang begitu luas, jelas 
merupakan tantangan bagi agama-agama untuk bisa saling "bertemu" antara satu dengan lainnya dalam menghadapi beragam persoalan kritis teologis yang sangat mendasar seputar "truth claim" dari masing-masing agama. Setiap agama "berkewajiban" memberi jawaban yang adequate atas persoalan mendasar seraya memberi "pembenaran" kepada agama lain, yang sama-sama mengklaim sebagai "jalan kebenaran” yang sama. Pluralisme dalam perjalanan historisitasnya telah semakin mengokohkan diri sebagai landasan sikap positif (baca: aktif dan bijaksana) untuk menerima kemajemukan dalam kehidupan sosial dan budaya, termasuk agama. Pluralisme pun dipahamkan sebagai bagian dari sikap dasar dalam beragama, yaitu sikap terbuka untuk berdialog dan menerima perbedaan secara adil, bukan sikap atau gagasan yang meyakini kebenaran semua agama, sebab jika demikian halnya maka yang terjadi adalah relativisme agama. Karenanya perlu selalu dibedakan antara pluralitas --yang memang telah dianggap sebagai sunnatullah-dengan pluralisme yang merupakan suatu sikap kejiwaan dan kedewasaan mental dalam menerima keragaman itu. Dengan demikian seorang pluralis harus mempelajari kebenaran agamaagama lain dengan sikap yang adil, proporsional, dan seimbang.

Dalam perspektif Filsafat Ketuhanan, percaya kepada Tuhan berarti melihat dan mengakui bahwa sesugguhnya hidup ini memiliki makna, atau dengan kata lain makna Ketuhanan bagi manusia itu akan terungkap melalui perilaku kehidupannya. Sudah sejak beberapa waktu lamanya diakui bahwa agama secara mendasar merupakan jalan untuk mencari dan menemukan "Sang Kebenaran" yaitu, Tuhan, dan jalan natural agama untuk menemukan-Nya adalah melalui otoritas wahyu. Kemudian dengan representasi, agama menawarkan serangkaian pemahaman imajinatif yang seringkali terekspresikan melalui simbol ataupun ungkapan metafor yang pada gilirannya menimbulkan berbagai friksi dan beragam forma dalam kehidupan keagamaan. Sejurus dengan itu, manusia tidak bisa menjadikan agama berpihak kepada manusia tanpa memahami bahwa agama itu sesungguhnya untuk manusia, bukan untuk Tuhan.

Manusia berupaya membuat definisi tentang Tuhan, tetapi definisi itu sesungguhnya tidak mencukupi. Segala upaya untuk 
mendefinisikan-Nya, berarti usaha untuk mengerdilkan-Nya dengan standar manusia, sehingga dengan demikian hendaknya manusia tidak mengurusi Tuhan tetapi mengurusi manusia itu sendiri. Manusia terhadap agama itu berposisi sebagai objek, artinya manusia hanya mempunyai hak untuk menegakkan aturan main beragama (baca: syariat) dari Tuhan. ${ }^{5}$ Dengan kata lain manusia tidak bisa membuat agama menjadi berpihak pada manusia tanpa memahaminya bahwa agama itu antroposentris, bukan untuk Tuhan (teosentris). Tuhan tak perlu dibela, tegas Gus Dur, namun kenyataannya banyak perbuatan manusia berdarah-darah yang mengatasnamakan dan membela agama dan Tuhan. Pada situasi seperti inilah harus dimengerti bahwa state of affair-nya adalah bahwa agama dari dulu memang untuk manusia, dan yang lebih penting adalah bahwa manusia harus mampu menghadirkan agama yang bervisi kemanusiaan.

Pertanyaan penting yang kemudian mengemuka dalam konteks problematika di atas adalah apakah dalam beragama itu manusia harus bersikap inklusivistik atau pluralistik? Wallabu a'lam bi al-shawab, tetapi seorang pluralis jelas bukan sekadar orang yang menerima perbedaan terhadap kebenaran agama yang berbeda, tetapi lebih jauh ia juga harus mempelajari kebenaran agama-agama lain dengan sikap yang adil. Ringkasnya, pluralisme adalah suatu landasan sikap positif (baca: aktif dan bijak) untuk menerima kemajemukan semua hal dalam kehidupan sosial dan budaya, termasuk agama. Lebih lanjut, pluralisme dapat dipahamkan sebagai bagian dari sikap dasar dalam beragama, yaitu sikap terbuka untuk berdialog dan menerima perbedaan secara adil. Karena itu tidak tepat jika pluralisme dimengerti sebagai sikap atau gagasan yang meyakini kebenaran semua agama, sebab jika demikian halnya maka gagasan pluralisme menjadi sama dengan relativisme agama, dan karenanya tak jarang dari mereka yang dianggap sesat dan murtad. Ketidakmengertian seperti inilah yang memaksa MUI (Majelis Ulama Indonesia) untuk mengeluarkan fatwa tentang haramnya pluralisme. Pengharaman terhadap gagasan tersebut oleh MUI berdampak luas dalam mempengaruhi cara pandang

${ }^{5}$ http://islamlib.com, diakses tanggal 20 April 2010 
masyarakat yang semakin kuat untuk memusuhi dan menolak kelompok lain agama atau kepercayaan. Hal itu terbukti dengan sikap penolakan masyarakat yang semakin lantang terhadap keberadaan Jama'ah tertentu yang difatwakan oleh MUI sebagai aliran sesat. ${ }^{6}$

Di tengah kekisruhan itu perlu selalu dibedakan dengan baik antara pluralitas dan pluralisme. Pluralitas adalah keragaman hidup yang telah menjadi sunnatullah, sedangkan pluralisme merupakan suatu sikap kejiwaan dan kedewasaan mental dalam menerima keragaman itu. Dengan demikian seorang pluralis bukan sekadar orang yang menerima perbedaan terhadap kebenaran agama yang berbeda tetapi lebih jauh ia juga harus mempelajari kebenaran agama-agama lain dengan sikap yang adil. Dapat diumpamakan dalam penganut teologi inklusif bahwa agama adalah sebagai cahaya-cahaya tapi yang paling terang adalah cahaya agamanya. Sementara seorang pluralis beranggapan bahwa semua agama bercahaya. Di sinilah terlihat perbedaan antara teologi inklusif dan pluralis. Manakala seseorang masih memandang semua agama sebagai cahaya, tetapi cahaya yang paling terang adalah agamanya sendiri, dan bahkan terjebak pada anggapan bahwa agama samawi lebih unggul dari agama bumi --karena agama samawi diyakini sebagai agama pemberian Tuhan kepada manusia-- maka seseorang itu berarti telah bersikap kurang adil, sehingga belum sepenuhnya pluralis, tetapi baru sebagai seorang inklusif.

Dalam Pluralisme tidak dikenal istilah uniformitas (penyeragaman atau penyamaan) karena pluralisme sesungguhnya adalah ingin merawat keberbedaan dalam kehidupan. Hal ini sudah barang tentu karena sesuai dengan fitrah manusia, perbedaan-perbedaan itu tidak pernah bisa ditolak. Namun demikian, sekali lagi pluralitas yang menjadi fitrah manusia itu tidak serta merta melahirkan pluralisme, karena perbedaan warna kulit, etnis, adat, budaya, maupun keyakinan keagamaan, dapat pula berujung "menolak yang lain", terlebih jika kesadaran akan perbedaan itu diwarnai dan dibentuk oleh pengalaman traumatis masa lampau yang telah bertumpuk.

6 http://islamlib.com/id/index.php?page=article\&id $=1032$, diakses tanggal 20 Maret 2010. 
Di sinilah arti penting sikap “menerima yang lain”, yakni sikap untuk menerima perbedaan dan keragaman yang tidak sekadar dalam bingkai toleransi (al-tasamuh), karena tasamuh hanya bermakna tenggang rasa terhadap pihak lain ketika mereka bersalah. Sedangkan "menerima yang lain" bermakna lebih aktif untuk menyongsong "yang lain” dan lebih jauh menyeberang melampaui tasamuh untuk menyongsong "sang liyan" tanpa harus terjerembab ke dalam kubangan "yang lain".

\section{Pluralitas sebagai Keniscayaan}

Bagi umat Islam, pluralitas bukan merupakan hal yang baru, toh sejak semula memang Islam sangat menghargai dan menjunjung tinggi terhadap "perbedaan" yang ada. Karena itu sesungguhnya adalah keniscayaan manakala setiap umat beragama menerima pluralitas secara wajar sebagaimana adanya, untuk kemudian secara sungguh-sungguh saling mendorong mewujudkan manfaat dan "mashlahah" dalam kehidupan bermasyarakat, seraya menyerahkan sepenuhnya segala bentuk perbedaan teologis dan segala bentuk "truth claim" hanya kepada Tuhan saja. Setiap "kita" seyogyanya menyadari bahwa sesungguhnya pluralitas itu secara teologis adalah sunnatullah yang karenanya maka keniscayaanya pun tak mungkin "kita" hindari. Kesadaran seperti ini akan menumbuhkan sikap keumatan yang komprehensif, proporsional dan seimbang mengenai pemahaman atas proses penggolongan yang terjadi baik secara historis maupun geografis, yang pada gilirannya akan menumbuhkan sikap penilaian yang juga proporsional dan seimbang pula terhadap pentingnya rasa handarbeni lan hangrungkebi (sense of belonging and preserving) terhadap realitas dan masyarakatnya. Inilah yang dalam Islam dikenal dengan ukhuwwah yang secara esensial sesungguhnya tidak terkait sama sekali dengan tatanan sosial monolitik tetapi tatanan sosial pluralistik.

Tatanan sosial yang didasarkan atas paham monolitik nyatanya justru menumbuhsuburkan paham sektarianisme yang

7Yang penulis maksud "kita" adalah umat Islam dan umat beragama yang lain. Baca al-Quran pada bagian akhir surat al- Fâthir (35): 43. 
nyata-nyata justru lebih dekat kepada syirik, yang secara luas dapat dipahami sebagai upaya memecah belah untuk kemudian menjadi bergolong-golong lalu secara pongah membanggakan golongannya sebagai yang terbaik bahkan yang paling benar. Oleh karena itulah maka Islam mengajarkan pluralitas keagamaan yang menandaskan pengertian dasar bahwa semua agama diberi kebebabasan untuk eksist baik secara pribadi maupun secara kelompok, bukan pengakuan akan kebenaran semua agama dalam bentuknya yang riil sehari-hari.

Secara teologis pandangan seperti ini akan memberi ruang bagi kemungkinan penciptaan hubungan agama satu dengan agama yang lain dengan cara yang lebih fairness untuk kemudian terbuka pula peluang bagi sebuah "dialog yang cerdas" dalam bingkai penggalian agama sebagai form of life, bukan sekedar truth claim atas agamanya sendiri. Hal ini tentu saja berlaku tidak saja antar tetapi juga inter umat beragama. Toh, manusia dalam keadaan yang primordial $^{8}$ selalu mengalami kesadaran yang penuh tentang "Yang Benar", "Yang Baik", dan "Yang Indah". Manusia, sesungguhnya tidak pernah mampu memalingkan diri dari mata hati-nya yang selalu terbuka bagi pertemuannya dengan Tuhannya sebagai peristiwa suci yang melambangkan perjanjian primordial. Manusia primordial akan selalu secara tepat mampu memahami siapa dirinya dan benar-benar memahami kodrat dirinya, yakni hamba yang menyembah kepada dan "menyatu" dalam Tuhannya. Perjanjian primordial ini menghasilkan apa yang secara teknis disebut fithrah. Oleh karena itu agama umat manusia yang paling asli adalah keterikatan pada Tuhan. Inilah hal yang paling mendasar dari perenialisme Islam, yakni: manusia pada dasarnya terikat pada perjanjian asalnya untuk selalu mengingat dan mengakui Tuhan. Seluruh agama pada dasarnya mengajarkan scientia sacra semacam itu yang tentunya lalu dikemas dalam berbagai bingkai metafisis masing-masing. ${ }^{9}$

8Sebagaimana tertulis dalam al-Qur'an surat al-Tîn (95): 4, Tuhan 'azza wa Jalla telah berfirman: laqad khalaqnâ al-insâna fî absani al-taqwîm (Sungguh telah Kami ciptakan manusia itu dalam sebaik-baik bentuk). Inilah keadaan primordial manusia yang sesungguhnya).

${ }^{9}$ Uraian yang paling memadai bisa dibaca dalam karya Seyyed Hossein Nasr, Knowledge and The Sacred (New York: State University of New York 


\section{Fungsi Filsafat dalam Distingsi Keagamaan}

Ada satu hal yang perlu dipertegas di sini bahwa filsafat dan agama memiliki "permainan" yang berbeda dalam hal Ketuhanan. Dalam perspektif filsafat, Tuhan merupakan "something" to be argued about sedangkan dalam perspektif agama Tuhan merupakan "something" to be sacrificed form yang tergambar di dalam segenap aktivitas masyarakat. Filsafat dalam kaitannya dengan form of life keagamaan merupakan alat elusidasi yaitu sebagai alat yang dapat digunakan untuk menjelaskan hal ihwal yang berkait erat dengan hal ihwal keagamaan sehingga diperoleh pemahaman yang mencukupi (adequate), bukan sebagai alat evaluasi atau pun advokasi.

Dalam kaitannya dengan hal ihwal Ketuhanan, filsafat tidak sama dengan theodicea kuno yang hanya digunakan untuk membela theisme atas atheisme ${ }^{10}$. Dengan kata lain, fungsi filsafat dalam kaitannya dengan distingsi Ketuhanan adalah sebagai alat analisis konseptual yang terkandung di dalam hal ihwal Ketuhanan. ${ }^{11}$ Melalui filsafat orang akan mengerti bahwa kata "Tuhan" memiliki tidak hanya satu arti, tetapi bermacammacam. Sebagai contoh, "Allah"-nya orang Arab sebelum Islam berbeda dengan "Allah"-nya Islam. "Allah"-nya orang Arab memiliki persekutuan dan anak yang semuanya minta "dilayani" dalam bentuk sajian dan ketundukan dari manusia, sedangkan "Allah"-nya Islam berada dalam pengertian paham monoteisme murni (strict monotheism); Tuhan dalam Islam dipahamkan sebagai Dzat Tunggal yang tidak sebanding dengan apa pun, tidak memerlukan persekutuan, tidak beranak dan tidak diperanakkan, Dia adalah awal dan akhir dari segala harapan. ${ }^{12}$

Press, 1989); John Herlihy, In Search of The Trubt: Contemporary Reflection on Tradisional Islamic Theme (Kuala Lumpur: Dewan Pustaka Islam, 1990).

${ }^{10}$ Theo Huijbers, Mencari Allah: Pengantar ke dalam Filsafat Ketubanan (Yogyakarta: Kanisius, 1992), 16.

${ }^{11}$ Alan Keightly, Wittgenstein, Grammar and God (London: Epworth Press, 1976), 67.

12 Selengkapnya silahkan dibaca: Nurcholish Madjid, "Beberapa Renungan Kehidupan Keagamaan untuk Generasi Mendatang", Jurnal 
Filsafat dan agama memang berbeda tetapi bukan untuk dibeda-bedakan apalagi dipertentangkan. Dengan filsafat orang akan bisa menilai secara kritis kesadaran dan keyakinannya akan eksistensi Tuhan, sehingga bisa mengerti betapa sesungguhnya tangkapan kesadaran tentang Tuhan bukan sekedar ide abstrak semata-mata melainkan suatu sikap hati yang berdasarkan keyakinan yang dinyatakan dalam iman. Dengan demikian, susungguhnya filsafat merupakan alat yang bisa digunakan untuk menunjukkan secara jelas dan tegas antara keyakinan akan eksistensi Tuhan --yang diakomodasi oleh agama-- dan takhayul yang sudah barang tentu jauh dari doktrin kebenaran dalam agama.

Filsafat dapat berfungsi sebagai jalan tengah yang dapat ditempuh menuju pemahaman mendalam dan substansial oleh masing-masing penganut agama atau kepercayaan yang sudah barang tentu memiliki distingsi konsep atau pun aplikasi serta implementasi atas makna Ketuhanan masing-masing. Hal ini penting untuk dipahami oleh siapa saja. Para pemikir kenamaan seperti Russell, Ayer, maupun Comte telah memberi pondasi yang cukup kuat untuk memahami bahwa seluruh deskripsi yang dilekatkan pada Tuhan tidak bisa diverifikasi kebenarannya maupun kesalahannya hanya semata-mata dengan rasionalitas. Hal ini karena Tuhan diyakini sebagai "Yang Abstrak" dan "Maha Ghaib", yang menurut Wittgenstein sepenuhnya "lie outside the world", sebuah wilayah yang "inexpressible" karena "beyond the limits of the world". Bagaimana mungkin manusia mempertahankan keyakinannya akan eksistensi Tuhan dan segala hal ihwal Ketuhanan jika sejak awal telah sama-sama meyakini bahwa Tuhan berada jauh di luar wilayah jangkauan rasionalitas. Oleh karena itu tidak mengherankan jika kaum agnostisistik menganggap pernyataan "Tuhan itu eksis" sama saja artinya dengan mengatakan "Tuhan itu tidak eksis". Bagi mereka kedua proposisi itu sama-sama tidak bisa diverifikasi. Itulah sebabnya Wittgenstein mengakui betapa sangat terbatasnya bahasa untuk dapat mengungkapkan kompleksitas dunia manusia, apalagi mengungkap tuntas rahasia "Sang Ghaib", Tuhan seru sekalian

Ulumul Qur"an, no. 1, vol. IV (1993), 12. Bandingkan dengan Edy A. Effendy (ed.), Dekonstruksi Islam Mą̧hab Ciputat (Bandung: Jaman, 1999). 
alam. Di sinilah posisi teologi bisa mengambil peranannya sebagai penerang bagi iman seseorang terhadap Tuhan.

Teologi diperlukan sebagai upaya pertanggungjawaban rasionalitas manusia. Memang Tuhan tidak bisa dicerna oleh rasionalitas manusia, namun dengan teologi orang akan bisa memahami dan menginterpretasikan hal ihwal Ketuhanan secara logis sehingga dapat menangkap makna dan nilai normatif serta pesan preskriptif di balik pesan deskriptif Kitab Suci. Dalam kaitan dan sejalan dengan itu filsafat akan menjadi sesuatu yang sangat diperlukan oleh agama agar bisa berkembang seiring dan sejalan dengan kemampuan rasionalitas manusia termaksud. Itulah alasan mengapa siapa saja perlu mengakui bahwa setiap kelompok dalam masyarakat masing-masing memiliki apa yang oleh Wittgenstein disebut language-game. Masing-masing permainan itu tidak dapat diperbandingkan atau pun dipersamakan dengan permainan serta form of life masyarakat yang lain. Demikian pula setiap individu dalam waktu yang bersamaan memiliki perbedaan sekaligus persamaan dengan individu yang lain. Dengan lain kata, permainan yang sama bisa saja memiliki aturan yang berbeda jika dipermainkan di tempat yang lain.

Pemahaman mendalam akan distingsi keyakinan Ketuhanan seperti itu jelas merupakan keperluan mendasar dalam form of life intern dan antar sesama umat beragama. Andai saja hal ini telah dipahami dan dipegang teguhi sejak semula tentu Syeikh Siti Jenar tidak harus bersimpuh untuk menghadapi kematiannya dalam slanghter-banch yang dibentuk oleh Wali Songo, tidak perlu pula terjadi konflik antara Islam dengan Hindu di India, antara Hindu dan Budhisme serta Islam di Sri Langka, antara Budhisme melawan Islam di Burma dan Thailand, antara Islam dengan Nasrani di Moro, antara Katholik dan Protestan di Irlandia, Syiah dan Sunni di Iraq bahkan mungkin masih banyak lagi konflik lain yang telah, sedang, dan akan terjadi akibat ketidakmampuan manusia yang percaya akan eksistensi Tuhan untuk memahami dan memainkan distingsi Ketuhanan dalam forma kehidupannya. Konflik-konflik tersebut memang bukan melulu konflik keagamaan, tetapi spektrum ketidakmampuan manusia yang percaya akan eksistensi Tuhan untuk memahami 
dan memainkan distingsi Ketuhanan dalam forma kehidupannya tergambar jelas telah turut andil atas terjadinya konflik-konflik tersebut. ${ }^{13}$

\section{Beberapa Aspek Penting dalam Agama}

Agama merupakan tema penting yang dapat membangkitkan perhatian serius terutama dalam masalah moral, etika, dan estetika. Secara makro masalah keagamaan akan mempengaruhi pembentukan world views, khususnya dalam kaitannya dengan dimensi ontologis. Agama dalam arti yang lebih luas selalu berkaitan dengan pertanyaan tentang ultimate concern yang mempunyai tiga karakter yaitu commitment, supreme value, dan inclusive perspective. ${ }^{14}$ Sementara Peter L. Berger menganggap bahwa agama merupakan suatu tirai suci (sacred canopy) yang melindungi manusia dari situasi nirmakna (meaningless), karenanya dalam situasi apapun agama perlu dipertahankan. ${ }^{15}$ Sementara itu Syamsul Arifin mengatakan bahwa diskusi tentang agama hampir

${ }^{13}$ Dalam filsafat analitik, Wittgenstein menawarkan language-game. Baginya berbahasa itu merupakan sesuatu yang bersifat publik, karena itu di dalam "permainan-bahasa" tentu ada aturan main yang disepakati oleh siapa saja yang terlibat di dalam permainan itu. Namun demikian, tentu masih saja ada ruang yang tersedia bagi individu pemain untuk berinovasi secara kreatif sehingga permainan itu lebih memikat dan menimbulkan semangat, baik bagi pemain maupun individu lain yang terlibat dalam permainan tersebut. Wittgenstein dalam Investigations seksi 142 menyatakan bahwa language-game sangat tergantung pada reaksi dan karakteristik ekspresi yang seringkali ditemukan dalam kehidupan sehari-hari. Dengan kata lain, sebagaimana yang ditegaskan oleh Wittgenstein dalam Investigations seksi 492 bahwa languagegame bukan merupakan bagian teori apa pun mengenai bahasa. Artinya, language-game merupakan sebentuk cara dalam upaya melihat dan memahami bahasa sebagai suatu fenomena. Menemukan bahasa berarti menemukan alat yang dapat digunakan untuk tujuan tertentu sesuai fungsi tertentu alat tersebut. Perspektif ini menggambarkan bahwa bahasa dapat digunakan untuk memenuhi kebutuhan dan kepentingan manusia dalam forma kehidupannya di dunia. Hal ini sebagaimana Geertz yang telah mengungkapkan bahwa man is an animal suspended in webs of significance he himself has spun.

${ }^{14}$ Win Usuluddin Bernadien (ed.), Tarian Tuhan (Yogyakarta: Apeiron Philotes, 2003), 219.

15Peter L. Berger, Kabar Angin dari Langit, Makna Teologi dalam Masyarakat Modern, ter. J.B. Sudarmanto (Jakarta: LP3ES, 1994), 16. 
dapat dipastikan akan bersinggungan dengan dua aspek yang menyatu, yaitu aspek realitas yang bercorak teologis dan aspek realitas yang bercorak historis-sosiologis. ${ }^{16}$

Dengan meminjam istilah Durkheim, Jalaluddin Rahmat menyebut dua aspek penting dalam agama, yaitu belief (ajaran) dan practices (keberagamaan) Ajaran adalah teks yang sakral dan menjadi sumber rujukan bagi pemeluk agama. Keberagamaan adalah perilaku yang bersumber langsung atau tidak langsung kepada Kitab Suci. Selanjutnya untuk memaknai istilah keberagamaan, Jalaluddin Rakhmat menggunakan istitilah religiosity. Menurutnya religiositas itu muncul dalam lima dimensi, yaitu dimensi ideologis, dimensi intelektual, dimensi eksperiensial, dimensi ritualistik, dan dimensi konsekuensial atau sosial. Dimensi ideologis berkenaan dengan seperangkat kepercayaan (beliefs) yang memberikan premis eksistensial untuk menjelaskan Tuhan, alam, dan mausia. Dimensi intelektual mengacu pada pengetahuan tentang agamanya. Dimensi eksperiensial merupakan bagian keagamaan yang bersifat afektif, yaitu keterlibatan emosional yang sentimental pada pelaksanaan ajaran agama. Dimensi ritualistik merujuk pada ritus-ritus keagamaan yang dianjurkan oleh agama. Dimensi konsekuensial atau sosial meliputi segala implikasi sosial dari pelaksanaan ajaran agama. ${ }^{17}$

Dalam kehidupan keagamaan masing-masing pemeluknya selalu memiliki truth claim yang mengarah pada eksklusivitas agama. Masing-masing pemeluk selalu saja mengklaim hanya agamanyalah yang paling benar, agama lain sesat dan menyesatkan (other religions are false paths, that misled their followers). Klaim atas kebenaran sesungguhnya boleh alias sah-sah saja, sepanjang klaim tersebut masih terbingkai dalam "wilayah" masing-masing, misalnya dogmatika agama merumuskan dan menempatkan kebenaran pengalaman manusia, dogmatika ilmu pengetahuan mengungkapkan dan menempatkan kebenaran dari

16 Syamsul Arifin, dkk., Spiritualitas Islam dan Peradaban Masa Depan (Yogyakarta: Sipress, 1996), 1.

${ }^{17}$ Jalaluddin Rakhmat, "Metodologi Penelitian Agama", dalam Metodologi Penelitian Agama Sebuah Pengantar, ed. Taufik Abdullah (Yogyakarta: Tiara Wacana, 1989), 92. 
pengalaman rasional-indrawi manusia, dan sebagainya. Klaim kebenaran dalam kehidupan keagamaan akan nampak jelas sekali manakala agama didekati dari sisi teologis.

M. Amin Abdullah menyebutkan tiga struktur fundamental bangunan pemikiran teologi. Pertama, kecenderungan untuk mengutamakan loyalitas kelompok sendiri yang sangat kuat. Kedua, keterlibatan pribadi (involvment) dan penghayatan yang begitu kental pekat kepada ajaran teologi yang diyakini kebenarannya. Ketiga, ungkapan perasaan dan pemikiran dengan menggunakan bahasa "actor" (pelaku), bukan bahasa pengamat (spectator). ${ }^{18}$ Bila ketiga karakteristik tersebut menyatu dalam diri seseorang atau kelompok akan menimbulkan andil yang sangat besar bagi terciptanya enclaves komunitas teologi yang cenderung bersifat eksklusif, emosional, dan kaku.

Implikasi dari eksklusivisme teologi akan membuat agama dalam situasi konfliktual bukan saja terhadap sesama agama melainkan juga terhadap entitas lain semisal pengetahuan ilmiah, sosial, politik, dan sebagainya. Anehnya eksklusivitas dan sikap keras tersebut diyakini mendapatkan justifikasi dari Kitab Suci masing-masing agama. Dalam Injil Yohanes 14: 6, misalnya, dapat ditemui ungkapan: "Akulah jalan dan kebenaran dan hidup. Tidak ada seorang pun yang datang kepada Bapa, kalau tidak melalui Aku'. Demikian juga di dalam Injil Kisah Para Rasul 4: 12 dapat ditemui ungkapan: "Dan keselamatan tidak ada di dalam siapa pun juga selain di dalam Dia, sebab di bawah kolong langit ini tidak ada nama lain yang diberikan kepada manusia yang olehnya kita dapat diselamatkan".

Pandangan eksklusif seperti itu memang dapat dilegitimasikan lewat Kitab Suci, tetapi itu bukan satu-satunya kemungkinan. Sejak konsili Vatikan II sudah jelas bahwa pandangan Gereja menjadi sangat terbuka ke arah adanya kebenaran dan keselamatan dalam agama-agama non Kristiani. Karl Rahner teolog besar yang menafsirkan konsili Vatikan II, merumuskan teologi inklusifnya kira-kira dengan mengatakan: other religions are implicit forms of our own religion.

18 M. Amin Abdullah, Studi Agama Normativitas atan Historisitas (Yogyakarta: Pustaka Pelajar, 1996), 14. 
Dalam pemikiran Islam, hal ihwal eksklusivisme ini juga terjadi secara ekspresif. Sejak awal di dalam Islam sudah ada konsep "abl al-kitab" yang diberi kedudukan kurang lebih setara dengan kelompok nonmuslim, tetapi selalu saja muncul sebuah cara penafsiran (interpretation a way) yang pada akhirnya mengarah pada situasi yang tidak sesuai lagi dengan bunyi tekstual Kitab Suci. Penafsiran eksklusif dalam Islam bisa muncul misalnya dalam pembacaan Surat Ali Imran (3): 19, berikut: Inna al-dîna inda Allâhi al-islâm (Sesungguhnya agama yang diridhai di sisi Allah hanyalah Islam), demikian juga Surat Âlî 'Imrân (3) ayat 85: Wa man yabtaghi ghaira al-islâmi dînan falan yuqbala minhu, wa buwa fi al-âkhirati min al-khâsirîn" (Barang siapa yang mencari agama selain dari agama Islam, maka sekali-kali tidaklah akan diterima (agama itu) darinya, dan dia di akhirat termasuk orangorang yang rugi). Padahal kalau ayat ini dibaca dengan semangat inklusif, yaitu semangat agama universal (al-dîn al-jâmi') dengan mengembalikan makna Islâm dalam arti generiknya sebagai pasrah sepenuhnya (kepada Allah), maka maknanya akan berbeda sekali; bahwa agama yang diterima di sisi Allah swt. adalah agama yang membawa kepasrahan kepada-Nya, jika tidak maka agama itu tidak akan diterima oleh-Nya dan dia di akhirat kelak termasuk orang yang merugi.

Sebagaimana yang telah ditulis Sukidi ${ }^{19}$, Nurcholis Madjid menjelaskan bahwa kata Islâm artinya adalah sikap pasrah ke hadirat Tuhan. Sikap pasrahlah yang menjadi satu-satunya ciri pokok agama yang benar. Inilah world view al-Qur'an, bahwa agama yang benar adalah Islâm, yaitu sikap berserah diri ke hadirat Tuhan. Bagi orang yang pasrah ke hadirat Tuhan dialah yang dinamakan al-muslim. Tanpa sikap pasrah kepada Tuhan, betapa pun seseorang itu mengaku sebagai muslim maka tidak akan diterima di sisi Tuhan, bahkan seseorang itu termasuk golongan orang yang merugi di akhirat kelak.

Dalam konteks ini sikap pasrah menjadi kualifikasi. Bukan saja kualifikasi seorang yang beragama Islam, tetapi "muslim" itu sendiri secara generik juga dapat menjadi kualifikasi bagi penganut lain, khususnya para abl al-kitab baik Yahudi maupun

19 Sukidi, Teologi Inklusif Cak Nur (Jakarta: Penerbit Kompas, 2001), 20. 
Kristen. Oleh karena itu konsekuensi teologis bagi umat beragama adalah siapa saja dia, baik yang beragama Islam, Yahudi, maupun Kristen yang benar-benar beriman kepada Tuhan dan Hari Kemudian, serta berbuat kebajikan, maka akan mendapat pahala di sisi Tuhan. Hal ini sesuai dengan firman Allah dalam Surat al-Baqarah (2: 62): Inna alladziyna âmanûw wa allad₹ৃina bâdûw wa al-nashârâ wa al-shâbi iyna man âmana billabi wa al-yawmi al-âkhiri wa 'amila shâlihan falabum ajrubum inda rabbibim wa lâ khaufun 'alaibim wa lâ bum yahzanûwn (Sesungguhnya orangorang yang beriman, dan orang-orang Yahudi dan Kristiani serta orang-orang yang benar-benar beriman kepada Allah, Hari Kemudian, dan berbuat kebajikan maka bagi mereka pahala dari sisi Tuhannya, dan tiadalah mereka memiliki rasa takut sedikit pun, dan tidaklah mereka bersedih hati).

Dengan kata lain, sesuai firman Tuhan tersebut terdapat jaminan teologis bagi umat beragama, apapun agamanya, untuk mendapatkan pahala (surga) dari Tuhan. Jelasnya, baik kaum muslimin maupun kaum Kristiani telah mewarisi begitu mendalam teologi eksklusif itu yang inti ajarannya adalah seperti ditulis oleh filosof agama terkemuka Alvin Plantinga berikut. "The tenets of one religions are in fact true; any propositions that are incompatible with these tenets are false" atau John Hick, "The exlusivists think that their description of God is the true description and the others are mistaken in sofar they differ from it".

Perspektif seperti itu jelas menganggap bahwa hanya ada satu jalan keselamatan, yaitu agama mereka sendiri, sebuah perspektif yang sudah barang tentu memiliki kecenderungan fanatisme, itulah sebabnya mengapa pada era postmodern ini diperlukan suatu perspektif baru dalam melihat "apa yang dipikirkan para pemeluk agama mengenai agama lain dibandingkan dengan agama sendiri".

\section{Keberagamaan Era Postmodern}

Menurut Coward, ${ }^{20}$ agama-agama pada umumnya dilahirkan dalam situasi plural sehingga respon terhadap pluralitas pun

${ }^{20}$ Harold Coward, Pluralisme Tantangan Bagi Agama-Agama (Yogyakarta: Kanisius, 1989), 168-9. 
mengalami evolusi historis yang panjang. Tantangan yang dihadapi pada masing-masing jaman tidak sama, apalagi pada situasi plural seperti pada masa kini tantangan itu agaknya jauh lebih besar dan semakin luar biasa. Coward mengatakan bahwa pluralisme keagamaan menghasilkan tiga tema dan prinsip umum. Pertama, pluralisme keagamaan dapat dipahami dengan paling baik dalam kaitannya dengan suatu logika yang melihat gejala ragam realitas transenden dalam berbagai agama. Kedua, bahwa ada suatu pengakuan bersama mengenai kualitas pengalaman agama partikular. Ketiga, bahwa spiritualitas dikenal dan diabsahkan melalui pengenaan kriteria sendiri pada agamaagama lain.

Di tengah postmodernitas, paling tidak bisa disebutkan dua persoalan keagamaan. Pertama, persoalan dekonstruksi wacana agama yang akan dihadapi dalam kondisi postmodernisme, dan kedua, bagaimana agama menghadapi pluralitas kebenaran yang dicanangkan oleh postmodernisme. Selanjutnya, secara filosofis sesungguhnya agama diturunkan sebagai kritik terhadap fenomena sosial yang dihadapi masyarakat waktu itu. ${ }^{21}$ Sebagai bukti, Islam diturunkan sebagai upaya menghancurkan ideologi yang sedang berkembang pada masyarakat Arab waktu itu, yang menurut paham postmodernisme disebut sebagai proses deideologisasi. Untuk menjaga fungsi kritis agama, umat beragama harus menjaga diri untuk tidak terjebak dalam kompensasi ideologisasi yang cenderung ber-stastus quo. Sebagai konsekuensi dari postmodernitas, maka pemahaman ajaran agama yang terlanjur menjadi ideologi perlu dibongkar kembali. Dekonstruksi dalam bidang keagamaan memang bisa menyebabkan munculnya beragam splinter group, namun jika visinya sejalan dengan postmodernisme yang ingin mengubah, memperbaiki, membongkar, bahkan merekonstruksi bangunan pemikiran keagamaan yang dinilai sudah usang untuk menghadapai tantangan masa depan, maka tentu sah-sah saja. Konstruksi kaku dan baku atas penghayatan agama merupakan

21 Alwi Shihab, Islam Inklusif Menuju Sikap Terbuka dalam Beragama (Bandung: Mizan. 1999), 147. Baca pula: M. Quraish Shihab, Membumikan alQur"an: Fungsi dan Peran Wabyu Dalam Kehidupan Masyarakat (Bandung: Mizan, 1992). 
produk masyarakat modern, oleh postmodernisme direkonstruksikan sesuai dengan keutuhan eksistensi manusia. Mitos keunggulan rasionalitas harus digoyahkan untuk menghindari pandangan yang bersifat mutlak. Ekses lain dari ideologisasi agama adalah dominasi subjek-objek (agama-para penganutnya) dan distorsi agama. Dengan dalih demi agama orang akan dapat melakukan pemaksaan bahkan sampai pada tindak kekerasan. Konflik antar umat beragama yang pernah terjadi di Maluku, Poso, dan wilayah lain di Indonesia bahkan di belahan bumi yang lain pun ibarat menimba air segar di sumur yang sangat dalam, semuanya meyakini ada dan banyak yang sudah menimbanya ke permukaan, tetapi setelah menimba dalam-dalam untuk menyiramkannya pada bara konflik antar umat beragama, ternyata sangat sulit. Dalam perpektif ini ideologisasi agama hanya akan menimbulkan aktualisasi diri yang palsu (palliative self-actualization), karena orang melakukan ajaran agama bukan berdasar kehendak hatinya melainkan ada kekuatan lain yang memaksa, yaitu ideologi. ${ }^{22}$ Dalam kaitan ini, Islam dengan tegas menolak absolutisme ide dan pemikiran teoritis, termasuk al-Qur'an.

Dalam al-Qur'an telah disebutkan bahwa untuk memahami dan mempelajari realitas sosial dengan segala aspek dan implikasinya harus melalui pengkajian intertekstual (kauniyahqauliyah). Al-Qur'an sesungguhnya "menolak" dirinya sebagai grand theory yang totaliter untuk menjelaskan suatu kebenaran. Sebagai sebuah teks atau narasi al-Qur'an secara eksplisit telah "mengakui" keterbatasannya sebagai representasi hakikat kebenaran Tuhan. Ini sesuai dengan postmodernisme, sebagaimana disebutkan oleh Derrida yang menolak pendefinisian terhadap sesuatu, menurutnya pendefinisian mempunyai sifat reduksi karena menganggap adanya suatu kebenaran tunggal (secara teoritis) yang sesuai dengan norma kenyataan. Dalam teori dekonstruksi Derrida melihat hubungan langsung antara kata-kata dan kenyataan atau bahasa sebagai representasi realitas adalah sebuah ilusi. Menurut Derrida dalam setiap kegiatan menulis kata-kata memiliki fungsi ganda yaitu

22 Bernadien, Dance ..., 224-5. 
setiap kata berbeda dengan yang lain sekaligus terbuka terhadap pemaknaan terus-menerus, karena itu tak pernah ada suatu makna yang dapat ditentukan definitif dalam suatu pernyataan. Apa yang disebut makna sesungguhunya merupakan hasil dari penandaan melalui pergantian kata yang terus-menerus dan karenanya tak pernah definitif melainkan terbuka untuk penafsiran yang tak pernah selesai. ${ }^{23}$

Dalam perspektif postmodernisme ditandaskan relativitas Kitab Suci. Sebagai sebuah teks, Kitab Suci bukanlah representasi pewahyuan yang otomatis jelas dan langsung mempertemukan seseorang dengan Tuhan yang mewahyukan. Seperti dalam teori dekonstruksi Derrida, teks bukan representasi kenyataan tetapi sebuah sistem penandaan. Dalam Kitab Suci yang ditemukan bukanlah realitas pewahyuan itu sendiri melainkan beragam rantam jejak (trace) realitas pewahyuan yang termuat dalam sistem penandaan. Realitas itu sendiri telah berlalu, yang tinggal adalah sebuah struktur internal teks yang harus siap ditafsir secara pluralistis ${ }^{24}$. Metode dekonstruksi yang merupakan salah satu tema penting dalam postmodernisme mungkin saja dapat digunakan untuk meluluhlantakkan agama sebagai sebuah teks, namun di balik itu ternyata dekonstruksi menyajikan wawasan baru: jalan keluar dari situasi totaliter, dominatif, dan eksploitatif yang kadang menyelimuti agama. Dengan demikian postmodernisme pada posisi ini sungguh memiliki titik singgung dengan agama. Dekonstruksi dapat diaplikasikan sebagai kerangka pendekatan untuk memahami agama. Jika memang demikian maka postmodernisme menuntut adanya revolusi pemikiran untuk membongkar beraneka simbol yang tertuang dalam Kitab Suci, dengan pendekatan yang multidimensi (intertextual). Artinya Kitab Suci ditempatkan dan dipahami sebagai grand theory yang aktif, relatif, dan dinamis bukan definisi simbol yang statis dan kaku. Dengan kata lain, upaya deideologisasi atau desakralisasi Kitab Suci merupakan keniscayaan. Melalui pendekatan postmodernisme ini upaya

${ }^{23}$ E. Sumaryono, Hermeneutik, Sebuah Metode Filsafat (Yogyakarta: Kanisius, 1999), 109.

${ }^{24}$ Baca pula: Martin Chen, "Agama dan Tayangan Postmodernism", dalam Basis (Yogyakarta, 1995), 112. 
teoritisasi Kitab Suci dilakukan secara kritis, dinamis, dan fungsional sehingga totalitas teori dapat dihindari. Jelasnya, postmodernisme dapat dijadikan paradigma baru dalam memahami dan mengaktualisasikan ajaran agama, di satu sisi, dan agama sendiri sebagai faktor pemersatu pada sisi yang lain. Tanpa adanya dasar nilai yang mengaktualisasikan maka postmodernisme hanya akan menjadi anarkisme berpikir yang cenderung absurd dan utopis naif. Agama juga akan menjadi mitos bila hanya dipahami secara simbolik ideologis.

\section{Catatan Akhir}

Dalam diskursus filsafat, postmodernisme memang belum memiliki sosok utuh yang dapat melahirkan "tubuh" filsafat tersendiri, namun demikian postmodernisme telah mampu tampil sebagai "pemberontak" terhadap modernisme dengan modernitasnya yang tiranik dan dominatif. Kehadiran postmodernisme telah mampu memberikan metode berpikir yang membebaskan dari segala bentuk dominasi. Manusia era postmodern tidak lagi terpasung dari dominasi satu ke dominasi yang lain. Para pendukung postmodernisme melihat bahwa cacat modernisme tidak hanya pada tataran epistemologi saja tetapi yang lebih serius adalah akibat yang ditimbulkannya, yaitu modernisme-westernisme. Kaum modernis Barat jelas menganggap tidak ada "language-game" yang valid di luar mereka. Di tangan mereka rule of the game di dalam form of life menjadi sangat monolitik dan absolut. Mereka bahkan menganggap rule of the game dan form of life di luar mereka sebagai tidak beradab sehingga tidak patut didengar. Di luar mereka orang tidak berhak menafsirkan realitas apalagi menciptakan narasi kehidupan kecuali sesuai dengan grammar of life orang Barat. Oleh karena itulah postmodernisme tampil untuk membela narasi kehidupan yang tergilas dan tersingkir oleh berbagai dimensi dominatifimperialistik yang disuguh-paksakan oleh modernism-westernism.

Arus pemikiran postmodernisme seolah-olah menjadi sebuah protes terhadap segala bentuk absolutisme, dan sebagai substansinya tak lain adalah pendekatan relativistik dan pluralistik yang dengan segala kerendahan hati mendengar dan memberi apresiasi kepada "the others". Pertanyaannya, jika 
postmodernisme memprotes terhadap segala bentuk absolutisme, maka bagaimanakah manusia dapat menangkap dan mendefinisikan Tuhan yang secara metafisis diyakini sebagai "The Truth and The Absolut Being?".

Dengan meminjam istilah dari hadits qudsi Tuhan tetaplah merupakan kanzan makbfiyyan baik di balik firman qauliyah-Nya maupun firman kosmologis-Nya (kauniyah). Tuhan sebagai "The Absolut Being" tidak mungkin bisa dipahami oleh manusia kecuali secara tidak langsung, parsial, dan relasional melalui "jejak-jejak" ciptaan-Nya lalu diapresiasi sesuai tingkat intelegensia masingmasing hamba-Nya. Manusia yang beriman hanya bisa mendekati dan menyapa Tuhan bukan "menguasasi" dan mendefinisikan Tuhan. Tuhan tidak bisa dipahami dan didefinisi secara tegas apalagi dipresentasikan sebagaimana kaum positivistik menghadirkan realita. Jika konsisten dengan logika dekonstruksi yang ditawarkan oleh postmodernisme, maka mau tidak mau sampailah seseorang pada sebuah konklusi bahwa pemahaman tentang Tuhan dan berbagai pesan-Nya tetap berada pada batas relativisme dan aproksimasi. Artinya segala sikap totaliter dan absolutistik yang membabi buta apalagi memaksakan atas nama truth claim tertentu harus didekonstruksi dan direlativisir.

Dalam tradisi Islam dekonstruksi bisa dilakukan, bahkan wajib, tetapi tentu sebagai langkah untuk melakukan rekonstruksi dan pendakian ruhani menuju "Realitas Absolut" yang tak seorang pun bisa mendefinisikan kedirian-Nya ${ }^{25}$. Toh setiap individu atau pun masyarakat memiliki language-game sendiri untuk membangun epistemologi form of life-nya sesuai dengan cara, pengalaman, kebutuhan, serta pilihan hidupnya masing-masing. Dengan lain kata setiap individu atau pun kelompok sosial memiliki language-game yang belum tentu bisa diterapkan oleh individu atau kelompok sosial yang lain. Dalam perspektif ini filsafat hermeneutik dianggap sebagai metode yang paling tepat untuk memahami dan mengembangkan postmodernisme. Sikap dialogis tetapi empati dan toleran agaknya menjadi keniscayaan dalam era postmodernisme.

25Ibid., 159-60. 
Bukankah Tuhan sesungguhnya tidak pernah memaksakan kehendak-Nya kepada makhluk? Iman yang otentik adalah pilihan yang otonom, bukan heteronom. Manusia secara otentik selalu mengarah kepada "Kebenaran" sehingga kebenaran pun sesungguhnya merupakan pilihan sejarah manusia. Dalam perspektif inilah Filsafat Ketuhanan menjadi media yang terbuka, santun, arif, dan rendah hati untuk melihat kembali cara "menangkap" Tuhan di sepanjang sejarah dan pemikiran umat manusia. Manusia sebagai bagian dari integral kenyataan senantiasa bergerak dan tercebur dalam realitas totalitas pengalaman. Manusia adalah kesadaran dalam samudera sifat dan gejala yang seakan tak bertepi, sehingga pengertian dan pengartian manusia tentang Tuhan pun menjadi sangat beragam, tetapi bukankah sesungguhnya Tuhan adalah "Kesempurnaan" yang luhur yang kepada-Nya semua yang ada, termasuk manusia, akan kembali. Oleh karena itu, seyogyanya interaksi dan interrelasi manusia dalam kehidupan keagamaannya harus selalu dibingkai dengan sikap saling menghormati dan menghargai baik intra maupun antar penganut, di samping penghayatan dan pengamalan masing-masing ajarannya secara kaffah. Jika hal ihwal Ketuhanan selalu berkait erat dengan perihal kehidupan keagamaan, maka Madjid pernah menawarkan beberapa refleksikontemplatif bagi kehidupan keagamaan untuk generasi mendatang agar manusia mampu menghadapi segala tantangan jaman. Menurutnya, adalah keharusan bagi agama untuk dapat diharapkan tampil kembali sebagai pemeran pembawa demokrasi, modernisasi, dan civilisasi. Umat beragama perlu kembali kepada makna dalil kaum ulama, yaitu: al-Munâfazhah 'alâ al-qadîm al-shâlih wa al-akhdžu bi al-jadîd al-ashlab. Inilah keterbukaan yang dinamis, dan ini pulalah jalan untuk membuat sebuah generasi yang kaya gagasan (resourceful). ${ }^{26}$

Dalam kaitannya dengan kehidupan keagamaan pada era postmodern ${ }^{27}$ agaknya patut diakui bahwa pada dasarnya iman

${ }^{26}$ Nurcholish Madjid "Beberapa Renungan Kehidupan Keagamaan untuk Generasi Mendatang", dalam Dekonstruksi Islam Maz̧hab Ciputat, ed. Edy A. Effendy (Bandung: Jaman, 1999), 46-7.

${ }^{27}$ Komaruddin Hidayat dan Muhammad Wahyuddin Nafis, Agama Masa Depan Perspektif Filsafat Perennial (Jakarta: Paramadina, 1995), 135. 
merupakan produk hubungan dialogis antara manusia dengan Tuhannya, yang senantiasa mencurahkan kasih-Nya dan akan selalu pula dirasa dan dijawab oleh hamba-Nya. Sejak semula manusia didesain dan diciptakan sebagai makhluk yang dialogis, berakal, sekaligus makhluk ruhani yang di dalamnya terdapat rub Ilabi yang kekal tak kenal kematian. Oleh karena itu agama era postmodern haruslah dapat dihayati sebagai sebuah wahana, ekspresi, dan manifestasi pencarian makna hidup manusia melalui aktualisasi kemanusiaanya. Kitab Suci harus diposisikan sebagai mitra dialogis hermeneutik yang diasaskan pada jernihnya hati nurani dan sehatnya akal budi. Hukum yang banyak tertuang dalam Kitab Suci seharusnya dilihat dengan cara yang dapat menawarkan pencerahan dan pembebasan, bukan pemasungan dan pembelengguan. Toh, agama berbicara tentang makna hidup, karenanya keberagamaan seseorang jelas akan meresap ke setiap denyut nadi kehidupannya. Agama mengajak manusia kepada keabadian hidup. Hal ini seharusnya semakin membukakan kesadaran untuk selalu menyadari bahwa kehidupan di dunia ini sesungguhnya merupakan sebagian perjalanan panjang untuk kembali pulang ke haribaan Tuhan "azza wa Jalla yang abadi, bukan "comdamné a être libre" perjalanan panjang yang merdeka tetapi tak pernah sampai, dan karenanya menjadi ziarah perjalanan yang sia-sia. Dalam perjalanan panjang hamba-Nya itu sesungguhnya Tuhan "Sang Maha Pengasih" telah membentangkan pertolongan bagi setiap hamba-Nya yang tersesat untuk segera bisa kembali pada jalan-Nya yang lurus. Jalan lurus itu sesungguhnya terbentang luas antara hati nurani setiap insan dan Tuhannya. Bentangan jalan lurus itu bisa menjauhi dan bisa pula mendekati atau bahkan menyatu melalui iman dan pencarian kebenaran secara tulus dan berkesinambungan menuju "Sang Kebenaran" itu sendiri, lalu dituangkan dan dilestarikan melalui tindakan nyata berupa amal saleh. Dengan begitu kesinambungan antara tafakkur dan tadzakeur, psikis dan fisik, jasmani dan ruhani, individu dan sosial, keselamatan dunia dan akhirat tetap terjaga dan selalu terhias dalam setiap perilaku keseharian umat manusia. Persoalannya sudah jelas, bagaimana manusia dapat menemukan Tuhan kembali yang (mungkin) telah menguap, lenyap, dan 
hilang dari pengalaman hidupnya?28. Sejurus dengan hal tersebut, Huijbers ${ }^{29}$ menegaskan bahwa pada masa sekarang ini orang perlu lebih sering bicara tentang hal ihwal Ketuhanan sebagaimana yang tampak dalam pengalaman. Teologi harus menjadi "cerita" tentang Tuhan yang hadir dalam hidup manusia. Setiap pemeluk agama seyogyanyalah mampu mengadaptasikan wahyu dengan situasi manusia dalam sejarah, dengan kebudayaan, dan dengan jamannya. Seandainya isi wahyu diserahkan sebagai ajaran yang kekal saja, maka manusia akan berhadapan dengan ketidakmampuannya untuk menilai warta Tuhan sebagai kabar gembira dari-Nya, karenanya manusia harus selalu berusaha untuk mencari jalan Tuhan, jalan keselamatan yang lurus(Al-din al நanîf). Dengan kata lain, setiap pemeluk agama harus menyadari betapa pun luas otonomi yang dimiliki akal manusia, namun wahyu tetap penting bagi ziarah manusia yang telah, sedang, dan yang akan dijalani. Hal ini berarti bahwa setiap pembicaraan tentang Tuhan harus kembali pada berbagai sumber kebenaran akal yang ditopang dengan beragam kebenaran tradisi yang terkandung di dalam wahyu, sehingga dengan wahyu setiap pengalaman pribadi akan mendapatkan tafsiran yang tepat. Hal ini juga berarti bahwa setiap pemeluk agama harus mampu pula melihat berbagai kebenaran yang dibawa oleh agama-agama lain. Barangkali, dari sini akan dapat dibangun sebuah harapan baru bagi manusia untuk bisa diantar secara eksistensial menuju suatu ekstase dalam arti harfiah: kepastian rutin dari hidup sehari-hari akan dilepaskan untuk menemui Tuhan yang akan membaharui segala semua. Lebih dari itu, memahami perjalanan sejarah filsafat dan agama yang seringkali mengalami clash, maka seyogyanya antara filsafat dan teologi ada suatu sistem koheren yang logis-religius. Teologi dan filsafat harus pula mengarah pada pertalian (engagement) atau pun commitment sehingga manusia bisa menjawab panggilan Tuhan.

Bertrand Russell ${ }^{30}$, mengatakan: "you will never know the deep despair of those whose life is aimles and void of purpose". Oleh karena itu

${ }^{28}$ Bernadien, Dance..., 248.

${ }^{29}$ Huijbers, Mencari..., 299-308.

${ }^{30}$ Bertrand Russell, The Impact of Science on Society (London: Unwin Paperback, 1985), 105. Artinya: "Anda tidak akan pernah tabu rasa putus asa 
penyembahan manusia kepada Tuhan haruslah berarti pencarian "Kebenaran" secara tulus, tanpa belenggu dan pembatasan, sadar atau pun tidak. Lebih dari itu, karena setiap manusia berpotensi untuk terbelenggu oleh kepercayaan palsu akibat pengaruh budaya sekelilingnya, maka manusia haruslah selalu berusaha membebaskan diri dari belenggu itu dengan menyatakan: Lâ ilâha..., kemudian harus tetap pada jalan pencarian "Kebenaran" yang tulus dengan menyatakan: illâ-lLâh, yaitu Tuhan yang sebenarnya, yang lepas dari representasi, visualisasi yang tidak mungkin diketahui oleh manusia, namun dapat dan harus selalu berusaha untuk mendekatkan diri padaNya, agar memperoleh perkenan dan ridla-Nya.

Dalam perspektif Islam ${ }^{31}$ pencarian "Kebenaran" yang tulus dan murni, dijelaskan di dalam al-Qur'an surat al-Rûm ayat 30 yang disebut dengan istilah Ђanîf, 32 yaitu sikap alami manusia yang memihak kepada "Yang Benar" dan "Yang Baik" sebagai kelanjutan dari fitrah-nya yang suci bersih, tegak, lurus, dan benar. Sikap mencari "Kebenaran" secara tulus dan murni (banifivyah) adalah sikap keagamaan yang benar, yang menjanjikan kebahagiaan sejati, yang tidak bersifat semu dan palsu (palliative). Sebaik-baik agama di sisi Allah ialah semangat mencari "Kebenaran" yang lapang, toleran, tidak sempit, tanpa kefanatikan, dan tidak membelenggu, serta memasung jiwa (albanifiyyat al-sambah). Jelasnya, intellectual enrichment tidak bisa ditawar-tawar lagi, baik tentang masa lalu, masa kini, maupun masa depan. Wa al-Lâh a lam bi al-shawâb.

yang mendalam, yang diderita oleb orang-orang yang hidupnya tanpa tujuan dan kehilangan makna”.

31 Madjid, Beberapa ..., 22.

32 Selengkapnya ayat tersebut berbunyi: "Fa aqim wajhaka li al-diyni haniyfan, fithrata Allâhi allatiy fathara al-nâsa "alaybâ, lâ tabdiyla li khalqi Allâhi dzâlika al-diynu al-qayyimu walakinna aktsara al-nâsi lâ ya'lamûwna” (Maka luruskanlah dirimu untuk menerima agama secara ţanîf. Itulah fithrah dari Allah yang telah menciptakan manusia di atasnya. Tidak ada perubahan dalam penciptaan Allah. Itulah agama yang tegak lurus, tetapi kebanyakan manusia tidak tahu). 


\section{Daftar Pustaka}

Alan Keightly, Wittgenstein, Grammar and God (London: Epworth Press, 1976).

Alwi Shihab, Islam Inklusif Menuju Sikap Terbuka dalam Beragama (Bandung: Mizan. 1999).

Bertrand Russell, The Impact of Science on Society (London: Unwin Paperback, 1985).

E. Sumaryono, Hermeneutik: Sebuah Metode Filsafat (Yogyakarta: Kanisius, 1999).

Edy A. Effendy (ed.), Dekonstruksi Islam Mą̧ab Ciputat (Bandung: Jaman, 1999).

Hamid Fahmy Zarkasyi dalam http://www.hidayatullah. com/kolom/ worldviews/10502-pluralisme-.html

Harold Coward, Pluralisme Tantangan Bagi Agama-Agama (Yogyakarta: Kanisius, 1989).

http://www.hidayatullah. com/kolom/worldviews/10502pluralisme-.html, diakses tanggal 20 Februari 2010.

http://en.wikipedia.org/wiki/Ninian_Smart, diakses tanggal 23

Maret 2010.

http:/ /islamlib.com, diakses tanggal 20 April 2010

http:/ /islamlib.com/id/index.php?page $=$ article\&id $=1032$,

diakses tanggal 20 Maret 2010.

Jalaluddin Rakhmat, "Metodologi Penelitian Agama", dalam Metodologi Penelitian Agama Sebuah Pengantar, ed. Taufik Abdullah (Yogyakarta: Tiara Wacana, 1989).

John Herlihy, In Search of The Trubt: Contemporary Reflection on

Tradisional Islamic Theme (Kuala Lumpur: Dewan Pustaka Islam, 1990).

Komaruddin Hidayat dan Muhammad Wahyuddin Nafis, Agama Masa Depan Perspektif Filsafat Perennial (Jakarta: Paramadina, 1995), 135.

M. Amin Abdullah, Studi Agama Normativitas atan Historisitas (Yogyakarta: Pustaka Pelajar, 1996).

M. Quraish Shihab, Membumikan al-Qur"an: Fungsi dan Peran Wabyu Dalam Kebidupan Masyarakat (Bandung: Mizan, 1992).

Martin Chen, "Agama dan Tayngan Postmodernism", dalam Basis (Yogyakarta, 1995). 
Nurcholish Madjid, "Beberapa Renungan Kehidupan Keagamaan untuk Generasi Mendatang", Jurnal Ulumul Qur"an, no. 1, vol. IV (1993).

Peter L. Berger, Kabar Angin dari Langit, Makna Teologi dalam Masyarakat Modern, ter. J.B. Sudarmanto (Jakarta: LP3ES, 1994).

Seyyed Hossein Nasr, Knowledge and The Sacred (New York: State University of New York Press, 1989).

Sukidi, Teologi Inklusif Cak Nur (Jakarta: Penerbit Kompas, 2001). Syamsul Arifin, dkk., Spiritualitas Islam dan Peradaban Masa Depan (Yogyakarta: Sipress, 1996).

Theo Huijbers, Mencari Allah: Pengantar ke dalam Filsafat Ketuhanan (Yogyakarta: Kanisius, 1992).

Win Usuluddin Bernadien (ed.), Tarian Tuban (Yogyakarta: Apeiron Philotes, 2003). 